\title{
Investigation of Facilities for an M-learning Environment
}

\author{
Mohaimen-Bin-Noor \\ Department of Computer Science, American International University-Bangladesh, Dhaka, Bangladesh \\ Email: mohaimen.niloy@aiub.edu
}

\section{Zahiduddin Ahmed}

Faculty of Computing, Universiti Malaysia Pahang, Pahang, Malaysia

Email: ahmedchayon11@gmail.com

\author{
Dr. Dip Nandi, Mashiour Rahman \\ Department of Computer Science, American International University-Bangladesh, Dhaka, Bangladesh \\ Email: \{dip.nandi, mashiour $\} @$ aiub.edu
}

Received: 30 August 2020; Accepted: 18 November 2020; Published: 08 February 2021

\begin{abstract}
The paper projected to study the field of m-learning focusing on investigating the facilities required to initiate an m-learning environment. Facilities and regular practices of conventional learning and e-learning was considered to find the potential facilities for m-learning environment. We used Integrated Tertiary Educational Supply Chain Model framework that stands on conventional education and illustrates the combined form of education supply chain and research supply chain model. Two surveys were conducted to collect data from students and teachers of higher education. The responses from both of the surveys have been presented and later compared with the findings from our studies of the existing learning environments. The significance of this research is in identifying the facilities for a learner and educator centric m-learning environment.
\end{abstract}

Index Terms: M-learning, Mobile Learning, Mobility, Ubiquitous, Self-Directed Learning, Informal Learning.

\section{Introduction}

Mobile learning is one of the major revolutions happening around us that demands a change in the philosophy of learning. It is considered as the third wave of learning where as traditional learning and e-learning are considered as the first and second respectively. In order to investigate for the facilities of an m-learning environment, we are required to discard and gain some of the fundamental ideas such as learner's attention, rhythm, learning style for these new dimensions of learning. The main purpose of this paper is to provide a better understanding of the existing facilities in different learning environments and consider them for improving m-learning framework. Two different surveys were undertaken in order to learn about the facilities that students and teachers feel comfortable with. We hope to distinguish the facilities from the survey data so that it opens further opportunities to establish more effective m-learning environment.

In this paper, we worked with a framework known as the ITESCM [1] (Integrated Tertiary Educational Supply Chain Management), which is based on conventional education and shows us the combined form of education supply chain and research supply chain model. We translated the framework to use in mobile learning. The framework is based on four factors and we worked with one of the factors which is facilities.

The main objective of our research was to investigate the facilities required to establish a mobile learning environment. In order to accomplish our main objective we had identified the requirements that both the students and the teachers need to use in a mobile learning environment. The main research question was what facilities are required to establish a mobile learning environment. To look for the answer of our main research question we had to find out what are the requirements that both the students and teachers need to use a mobile learning environment.

We organized the paper with a small introduction of mobile learning in section I. After that we described about traditional learning, e-learning and m-learning along with their facilities in the section II. In section III, we explained our research methodology. Then we presented the data obtained from our surveys in section IV. In section V, we provided a brief discussion over the survey data relating with our literature review. Finally we concluded the paper in section VI by summarizing our outcomes and an idea to conduct future researches. 


\section{Background Study}

In traditional learning environment universities offer a wide range of modern facilities to their students including lecture halls, libraries and laboratories [1] to ensure students are at comfortable learning environment. Modern facilities in the university are represented by online database, e-journal, digital library etc. [2]. To ensure these facilities are also available in m-learning environments an online library can be implemented consisting of various modern books and journals. A complement of lecture hall can be an open chat room during scheduled class for students and faculty members. Universities also provide internet and computer facilities. Although computer labs are densely packed with desktop computers, most of them are usually unavailable for self-access as they are almost constantly reserved for teaching classes [3].

In time of class tests, quizzes and exams, guidelines with counseling, lecture sheets and maintaining a good relationship with faculty members and other students play a vital role [4]. Faculty members needs to provide necessary lecture sheets to students for better understanding of subject and guidelines for exams and students will be able to discuss their short comings with their faculty through audio-video chat.

The adoption of e-learning systems has been growing in academia. In 2004, the e-learning market was worth more than US $\$ 18$ billion worldwide. In Middle East, e-learning projects were expected to exceed a compound average growth rate of $32 \%$ by 2008 [5].

According to [6], to offer e-learning, a country must have strong telecommunication system, strong and cheap internet service, Wi-Fi technology and expert teams for designing educative materials and resources. On a similar thought, paper [7] highlighted that an appropriately designed and structured content management system allows the students to browse and interact with the content of the courses. E-learning literatures also reveal that access to elearning can be challenged by issues such as persistent supply of electricity, high cost of hardware like personal computers and laptops, technophobia systems in the country, poor attitude towards ICT by students, poor availability of e-learning software and instructors unwillingness to incorporate e-learning approach in teaching [8].

E-Quarium was designed by e-learning academy with the several social learning styles in mind like individual learning, active learning hub and chill-out zone. Individual learning style refers to a seating area where a student prefers to study on his own. Plenty of charging stations are available there. Active learning hub refers to when a student prefers to discuss educational contents in a larger group with media support and digital driven collaboration. A chill-out zone is another sort of seating area where a student prefers to engage in an academic discussion or reading a book.

The term m-learning is generally used to describe a learning environment where students and instructors can access a learning system over a wireless network using mobile devices [9]. It is a subset of e-learning [10]. It is a spontaneous learning environment [11] and referred as the mode of learning in which learners may move within different physical and virtual locations to participate and interact with other people, information, or systems anywhere, anytime [12].

M-learning is an approach to e-learning that utilizes mobile devices [13]. In other words, m-learning means mobility of learning where mobility can be conceptualized in different ways such as mobility of the device, mobility of the user, mobility of the service [14]. Unlike desktop e-learning, m-learning has the benefits of mobility and its supporting platform, which can be summarized as ubiquitous, localized and personalized [15]. Mobile learning is ubiquitous in a sense that it can occur anytime, anywhere, anyplace. Localization is a specific strength of mobile devices as it can provide service according to user's location. Last of all, personalization means targeting learning materials as much as possible in a difficult navigation of a small mobile screen [15]. Mobile learning has also been defined as any sort of learning that happens when the learner is not at a fixed predetermined location or learning that happens when the learner takes advantage of the learning opportunities offered by mobile technology [16]. It is any form of learning that happens when mediated through a mobile device [17].

Mobile learning refers to the ability to obtain or provide educational content on personal pocket devices such as smart phones, PDAs and mobile phones. Digital learning assets enable a learner to learn beyond typical learning environment. So, portions of life those were never considered accessible for learning due to lack of connectivity are now potential learning opportunities for the mobile learner [16]. M-learning is also cost-efficient and helps students to learn more without traditional restrictions [3]. In an m-learning environment, educational contents should be designed for minimum equipment in order to be feasible on most regular phones. Limited battery life, limited key and screen sizes on mobile devices and variable network coverage in some rural areas [10] may make it a tough to accommodate all the facilities.

One of the most promising features of m-learning is performing activities collaboratively [14]. According to [18] mobile learning environment should provide opportunities so that peers can discuss among themselves and recorded audio-video clips and other course contents are accessible. M-learning environment should also promote high level learning by enabling the students to collaborate on educational problems. Researchers in [19] found that justification of posts, clarification of ideas, critical discussion of contribution, suggesting solutions and periodic feedback from the instructors is highly valued among the students. Another research showed that students were interested in podcasts of 
lectures as well as quick SMS notification to keep themselves updated about lecture times, assignment due dates and various university events [20].

In study [7] researchers found that social networking sites influenced students to suggest for features like receiving notifications when their queries get responded, easier way to create and respond to quires and flexible way to download content. The authors in [18] also noted that students can contact their course instructors whenever they need through mobile phone and using different social networking apps increases the connection and intimacy between them.

Digital revolution enables real-time assessment of student performance. As a result, students do not require receiving feedback regarding their skill mastery. Teachers can now embed pop-up quizzes in online and students can be evaluated on an on-going basis [21]. This leads us to conclude from this data that providing assessment marks for contributing to the discussion forum does have an impact on the participation of fully online students [19].

In [3] some challenges of m-learning were mentioned. It was said that m-learning environment might create a feeling of being isolated. Furthermore, as mobile technologies are upgrading at a rapid pace, lots of outdated resources are found. A virtual learning environment can be divided into four parts [22]: presentation, activities, communications and administration. Presentation refers to any functions related to new materials, activities refers to all kind of student's activities; communications refers to communication between students and teachers and administration functions refers to administrative works like enrolment, registration and payment [5].

Educational institutions often fail to achieve substantial results with their mobile learning initiatives [23]. Although the rapid proliferation of mobile applications has outpaced the traditional software applications, these applications cannot be applied directly in mobile devices because of different mobile platforms, different hardware makers [3] and lack of any well-established mobile user interface design guideline [24, 25]. As m-learning is a form of distant learning it may make it easier to cheat and preventing it has also been stated as a challenge [3]. A way to face this challenge is to make sure that the device is being always controlled by the user which is yet another challenge [5]. As Internet and computers become very important educational tools [3], there exist a few applications in the market to assist conducting educational activities. Again, different mobile hardware makers such as HTC, Google, Samsung, Nokia, Apple etc. uses different platforms such as android, windows, iOS, etc. So, it is a challenge to make all the facilities available for all of them [5].

Researchers behind m-learning technology have proposed that m-learning should be standardized to ensure that it operates smoothly within the existing IT infrastructure [26] of educational institutes. Developers also must take into account the environment in which the application will be used while developing mobile applications [27]. It is also suggested that academic institutions introducing m-learning should focus on system quality, content quality, and service quality [28]. Furthermore, mobile technology should be easy to use in the classroom and compatible with the way students use educational resources [29]. Lastly, being an informal and self-directed learning environment, a user should get the facility to configure the environment according to his preferences. In [7], students also suggested that clear and customized information can result in a better learning experience. Providing this facility is also a challenge of $\mathrm{m}$ learning environment [5].

\section{Research Methodology}

In [1], researchers presented that to provide quality education, four factors are needed to be analyzed. They are: program establishment, university culture, faculty capabilities and facilities. Among these four factors we have investigated about facilities in our research. A university provides both direct and indirect facilities to its students for their academic studies and researches. Lecture hall, library, IT facilities, digital library and e-journal facilities are directly related with education whereas residence facilities and transport facilities are indirectly related with education. If proper facilities are not provided, students will not be able to receive proper education.

In our study we followed design based action research. An action research is a well-disciplined inquiry process which is conducted by and for the practitioners who are participating in the action [30]. Design based action research is a research methodology where the researchers have a vision on how the reality should be and collaboration is always made with people who would utilize the outcome of the research. Design based action research aims to develop educational practices through systematic and iterative analysis, design, development and implementation, based on collaboration between researchers and practitioners [31]. Researchers in [32] have argued that, practitioners and researchers collaborate together in design based research to bring out changes by drawing design constraints from not only the local context but also the researcher's agenda. They also mentioned that design based research can help to create and extend knowledge about developing, enacting, and sustaining innovative learning environments. It not only intends to inquire the nature of learning in a complex system but also to enhance theories of learning.

In our research data was collected by survey to find out about the participants anticipation on different facilities of an m-learning environment. According to [33] survey is a mean of gathering information about the characteristics, actions, or opinions of a large group of people, referred to as a population. A major characteristic of surveys directed for research purposes is that information is usually composed about only a portion of the study population, but it is collected in such a way as to be capable to simplify the outcomes to the population [33]. 
We conducted the survey in "X" University. 100 students and 20 faculty members participated in the survey. The students were selected through a systematic random sampling procedure where we selected four courses from different years of study. All the students were studying for bachelor's level computing degrees. The survey questionnaire for faculty members were distributed to all the members of the faculty and 20 out of 32 participated. The survey questionnaire is attached in appendix A. We used different survey questionnaire for students and faculties so that we could justify the perspectives of both cases. We examined the raw data after clustering the questions into associated sections and also generated a graphical appearance of the data. After examining each cluster we composed a summary of the outcomes and derived a conclusion on how m-learning is being approached by both students and teachers.

\section{Findings}

We divided the questionnaire for students into seven categories. Category A has only one question (Q1) indicating willingness of using mobile devices, Category B has two questions (Q2, Q3) indicating state of internet access of the students' mobile devices, Category C has five questions (Q4 - Q8) representing significance of course materials in mobile and Comfort of using it, Category D has five questions (Q9 - Q13) representing tools that students want to use in mobile phone, Category E has two questions (Q14, Q15) indicating preferred form of education, Category F has two questions (Q16, Q17) highlighting the drawbacks and possible improvements and Category G has one question (Q18) reflecting the degree of success.

We also divided the questionnaire for teachers into five categories. Category A has three questions (Q1-Q3) indicating the usage of mobile phones in teaching procedure, Category B has four questions (Q4 - Q7) indicating willingness of using mobile phones for teaching, Category $\mathrm{C}$ has only one question (Q8) representing activities performed in mobile phones, Category D has four questions (Q9 - Q12) highlighting the drawbacks and possible improvements and Category E has four questions (Q13 - Q16) reflecting teacher's vision on M-learning.

Both of the survey responses have been presented below:

Table 1. Responses of student survey Q1 to Q5

\begin{tabular}{|c|c|c|}
\hline \multirow{2}{*}{ Questions } & Responses & $\begin{array}{c}\text { Response } \\
\text { Rate }\end{array}$ \\
\hline \multirow{2}{*}{ Q1 } & Yes & $95 \%$ \\
\cline { 2 - 3 } & No & $5 \%$ \\
\hline \multirow{2}{*}{ Q2 } & Yes & $88 \%$ \\
\cline { 2 - 3 } & No & $12 \%$ \\
\hline \multirow{2}{*}{ Q3 } & Yes & $98 \%$ \\
\cline { 2 - 3 } & No & $2 \%$ \\
\hline \multirow{2}{*}{ Q4 } & Yes & $44 \%$ \\
\cline { 2 - 3 } & No & $56 \%$ \\
\hline \multirow{2}{*}{ Q5 } & Yes & $53 \%$ \\
\cline { 2 - 3 } & No & $47 \%$ \\
\hline
\end{tabular}

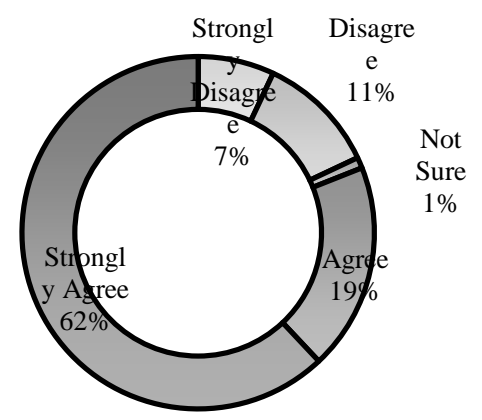

Fig.1. Response of Student Survey Q6 


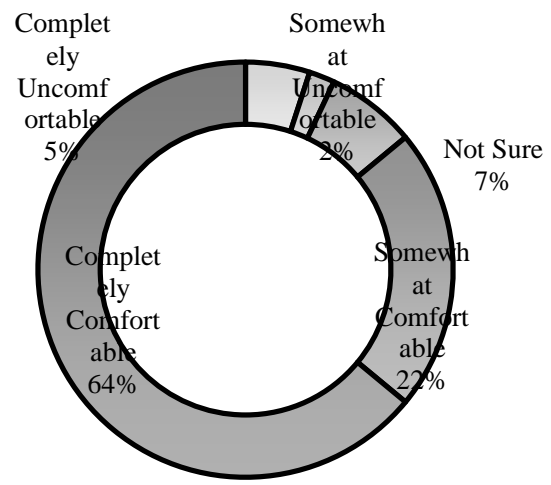

Fig.2. Response of Student Survey Q7

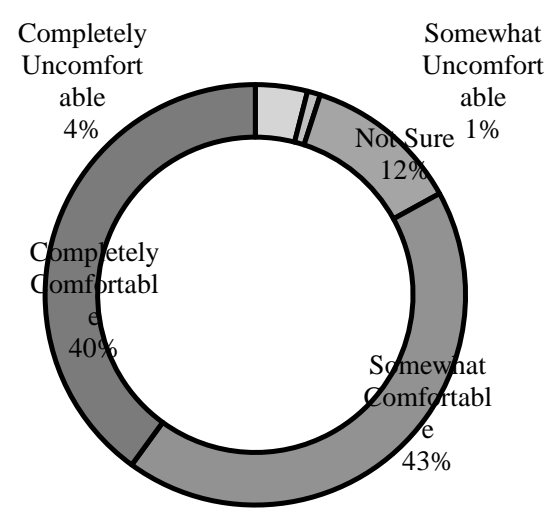

Fig.3. Response of Student Survey Q8

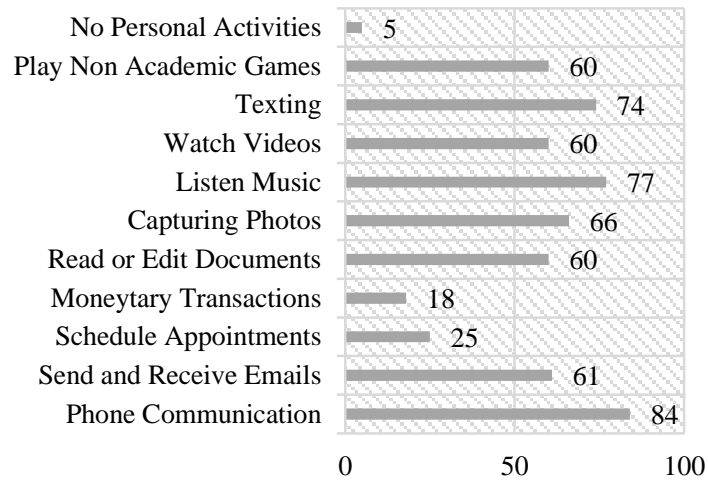

Fig.4. Response of Student Survey Q9 


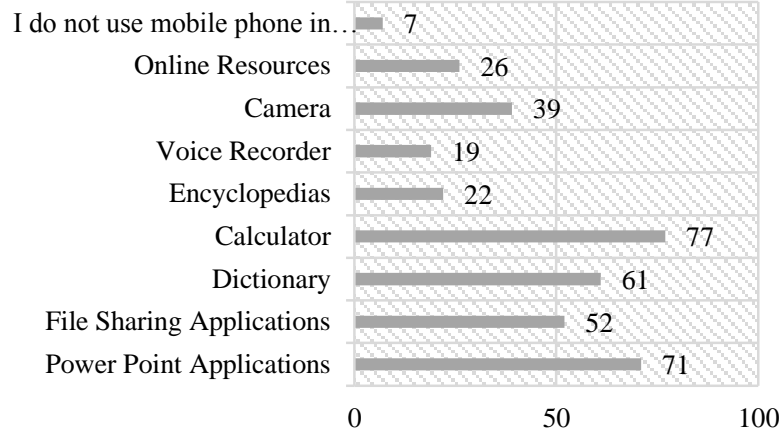

Fig.5. Response of Student Survey Q10

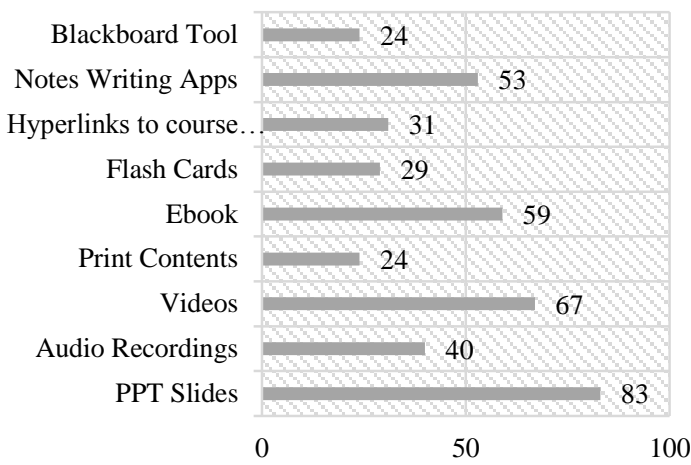

Fig.6. Response of Student Survey Q11

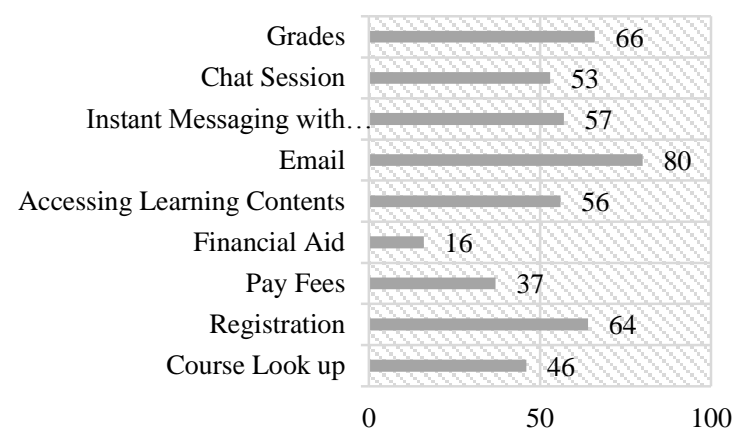

Fig.7. Response of Student Survey Q12

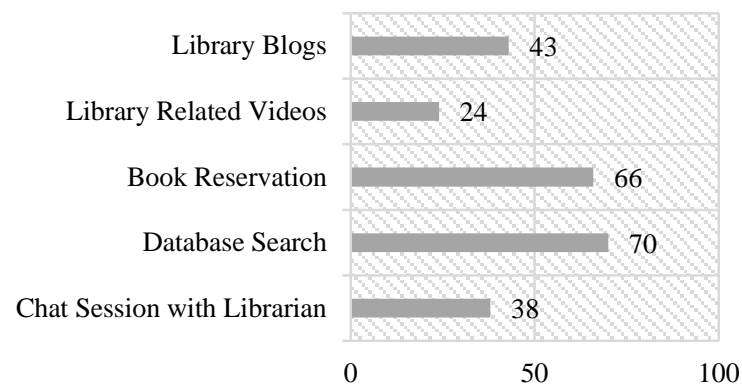

Fig.8. Response of Student Survey Q13 


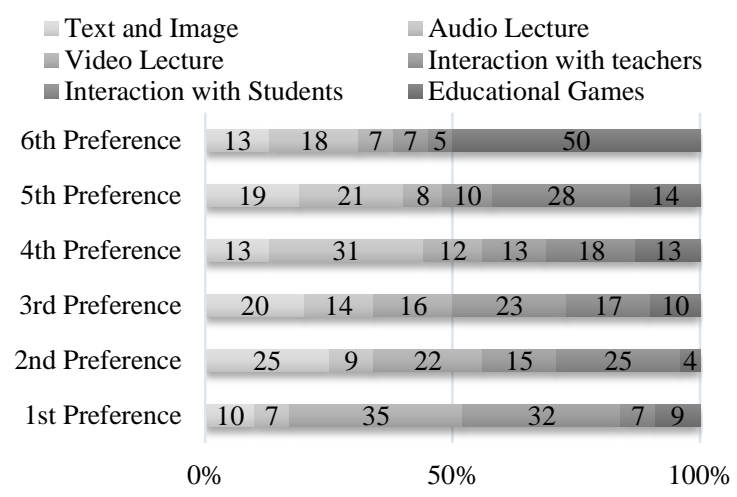

Fig.9. Response of Student Survey Q14

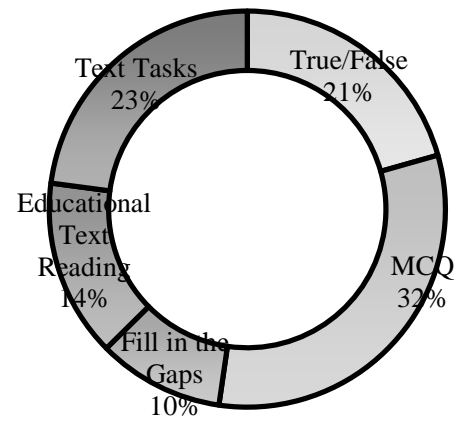

Fig.10. Response of Student Survey Q15

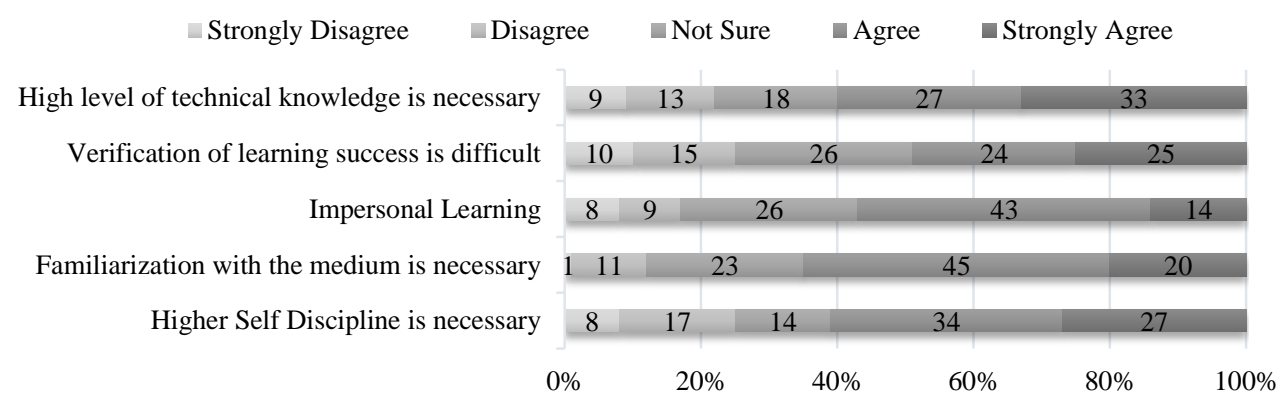

Fig.11. Response of Student Survey Q16

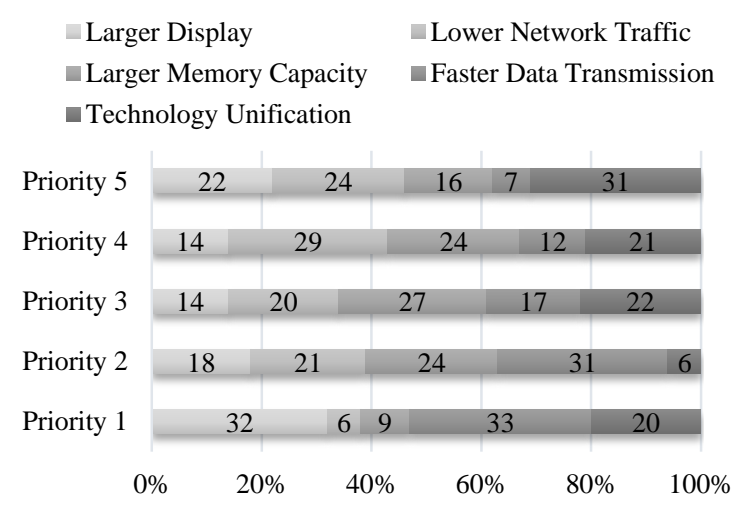

Fig.12. Response of Student Survey Q17 


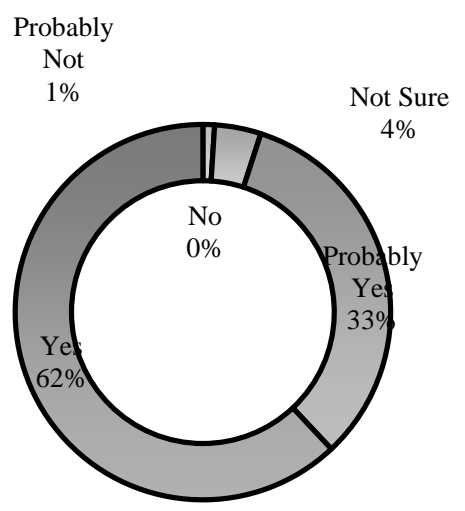

Fig 13. Response of Student Survey Q18

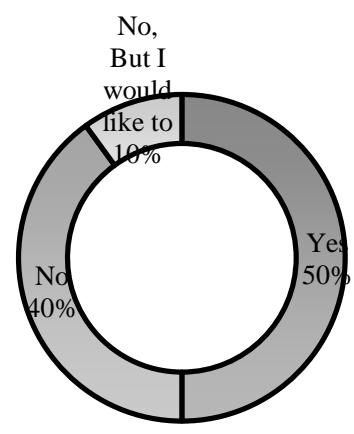

Fig.14. Response of Teachers Survey Q1

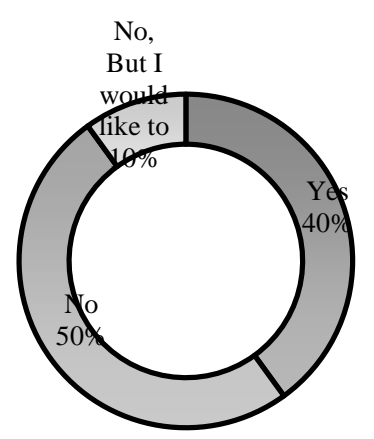

Fig.15. Response of Teachers Survey Q2

Table 2. Responses of teacher survey Q3 to Q7

\begin{tabular}{|c|c|c|}
\hline Questions & Responses & $\begin{array}{c}\text { Response } \\
\text { Rate }\end{array}$ \\
\hline \multirow{2}{*}{ Q3 } & Yes & $30 \%$ \\
\cline { 2 - 3 } & No & $70 \%$ \\
\hline \multirow{2}{*}{ Q4 } & Yes & $65 \%$ \\
\cline { 2 - 3 } & No & $35 \%$ \\
\hline \multirow{2}{*}{ Q5 } & Yes & $20 \%$ \\
\cline { 2 - 3 } & No & $80 \%$ \\
\hline \multirow{2}{*}{ Q6 } & Yes & $50 \%$ \\
\cline { 2 - 3 } & No & $50 \%$ \\
\hline \multirow{2}{*}{ Q7 } & Yes & $50 \%$ \\
\cline { 2 - 3 } & No & $50 \%$ \\
\hline
\end{tabular}


Fig.16. Response of Teachers Survey Q8

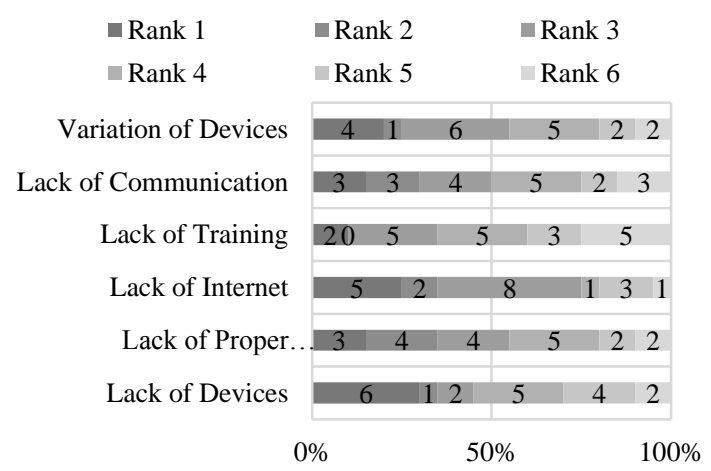

Fig.17. Response of Teachers Survey Q9

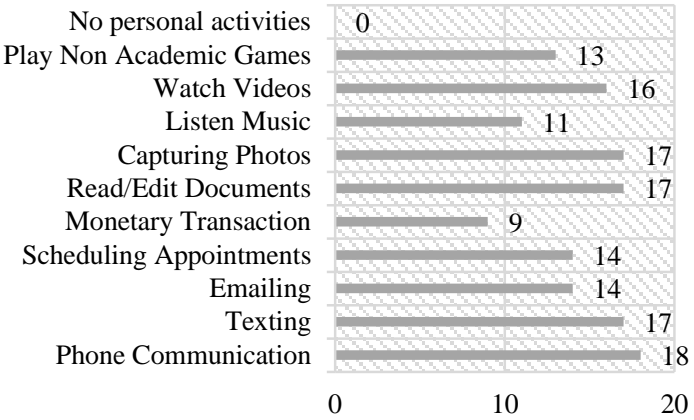

\section{Fig.17. Response of Teachers Survey Q9}

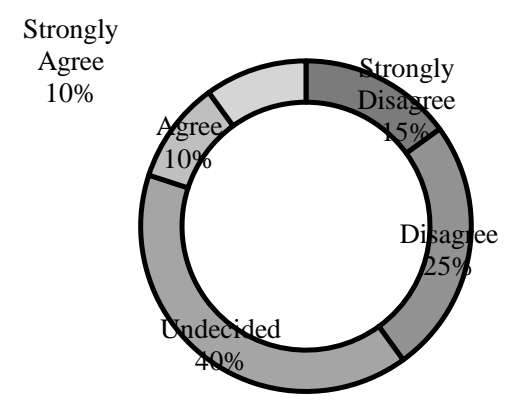

Fig.18. Response of Teachers Survey Q10

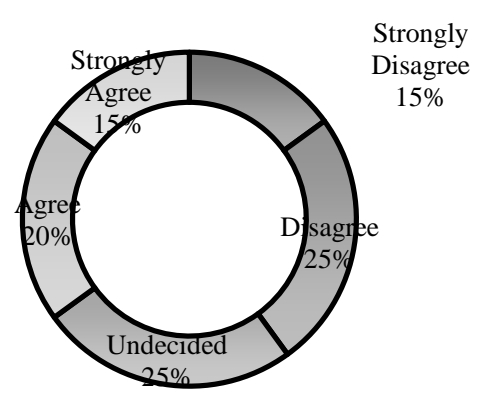

Fig.19. Response of Teachers Survey Q11 


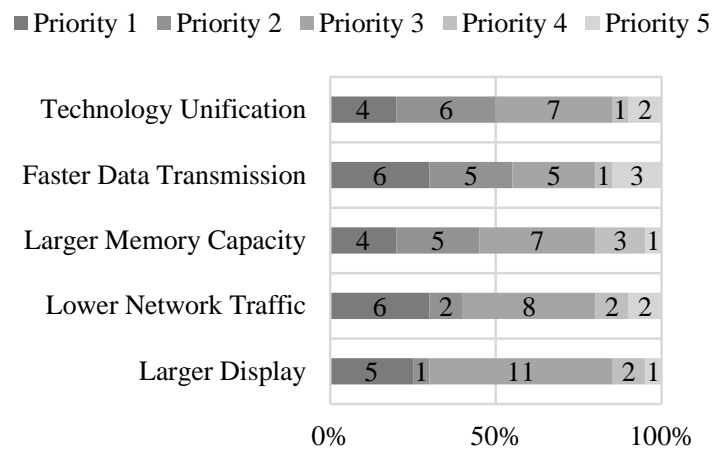

Fig.20. Response of Teachers Survey Q12

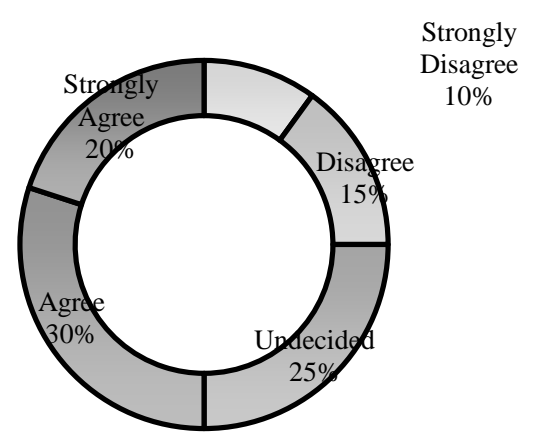

Fig.21. Response of Teachers Survey Q13

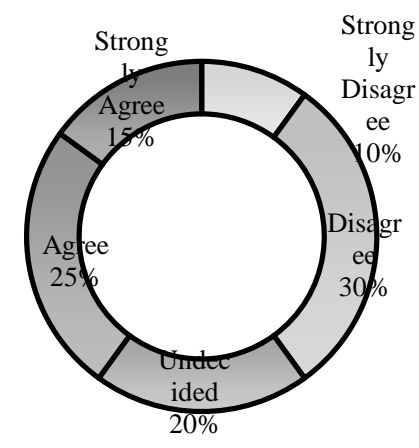

Fig.22. Response of Teachers Survey Q14

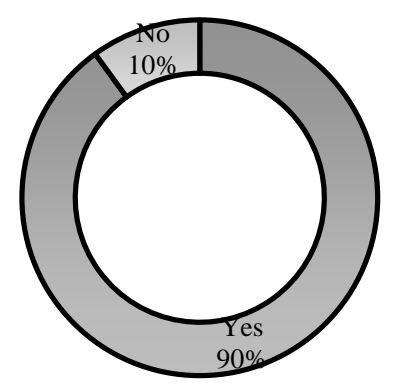

Fig 23. Response of Teachers Survey Q15 


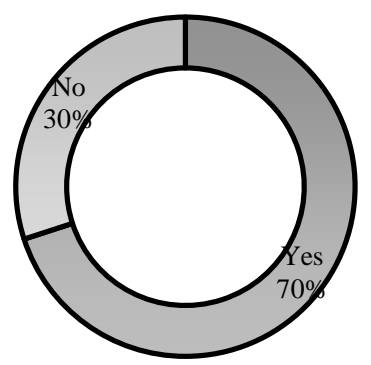

Fig 24. Response of Teachers Survey Q16

\section{Discussion}

Table 3. Discussion based on survey data of students

\begin{tabular}{|c|c|}
\hline Category & Summary of student's survey data \\
\hline $\begin{array}{l}\text { Willingness of using } \\
\text { mobile devices }\end{array}$ & $\begin{array}{l}\text { According to the authors of [20] students were interested in receiving lectures, assignments and notices regarding } \\
\text { different class activities through mobile phone. Our research has also found that } 95 \% \text { students wanted to use mobile } \\
\text { devices for learning purpose. }\end{array}$ \\
\hline $\begin{array}{l}\text { State of internet access } \\
\text { of the students' mobile } \\
\text { devices }\end{array}$ & $\begin{array}{l}\text { In [6] it was mentioned that strong telecommunication and internet infrastructures are required for e-learning. As, m- } \\
\text { learning is a subset of e-learning [10], the same thing is also required for m-learning. Paper [34] also mentioned that } \\
\text { stable internet connectivity is required to extract maximum benefit of m-learning. From our literature review and our } \\
\text { survey responses, we found that } 88 \% \text { of students use cellular data connections and } 98 \% \text { of students can access Wi-Fi } \\
\text { network from their mobile phone. It enables them to access learning materials through internet. }\end{array}$ \\
\hline $\begin{array}{l}\text { Significance of course } \\
\text { materials in mobile } \\
\text { and Comfort of using } \\
\text { them }\end{array}$ & $\begin{array}{l}\text { From our survey responses we found that } 56 \% \text { of students do not feel comfortable reading books as books are large } \\
\text { reading materials and it is difficult to do a lot of reading in a device with small display. We also found in [10] that } \\
\text { small screen size of a mobile phone may make it harder to facilitate all the facilities. } \\
\text { Paper [15] mentioned that m-learning can occur anytime and anyplace. } 53 \% \text { students expressed that they will be } \\
\text { comfortable in attending exams through mobile phones as they do not need to confine themselves in a particular place } \\
\text { for it. } \\
\text { From our literature review we learned that students were interested to have course materials on their phones [20]. Our } \\
\text { survey responses indicated that students agreed on the fact that having course materials in their mobile phone would be } \\
\text { beneficial for their study process. It will help the students to access course materials on the go. Furthermore, these } \\
\text { materials should be distributed in different formats like audio, video, pdf, ppt or even html. } \\
\text { According to [21], students receive real time assessments of their performances and a major portion of the students } \\
\text { mentioned that they would be comfortable in receiving grades in their mobile phone. They also expressed that they } \\
\text { would be comfortable if the teachers contact them and guide them through mobile devices. The students consider it to } \\
\text { be an assurance that their teachers will be available to assist them whenever they need. We have also found the same } \\
\text { from }[4,20] \text {. }\end{array}$ \\
\hline $\begin{array}{l}\text { Tools that students } \\
\text { want to use in mobile } \\
\text { phone }\end{array}$ & $\begin{array}{l}\text { Our survey responses illustrates that students not only use mobile phones for communication and entertainment } \\
\text { purposes but also they use it for capturing photos and reading/editing documents A majority of the students expressed } \\
\text { that they use the calculator, power point applications, file sharing applications and camera applications in their phone. } \\
\text { A few students also said that they use online resources through their phones. Students also expressed that they would } \\
\text { be interested in accessing power point slides, videos, notes writing applications and e-books in their mobile phone. } \\
\text { Some of them also mentioned about accessing audio recordings, flash cards and hyperlinks to course materials. } \\
\text { In another question, the students responded that they would be interested in accessing their emails, grades, course } \\
\text { registrations, chat/instant messages and learning contents through their mobile phones. Many students also mentioned } \\
\text { that they will be interested in searching book database and reserving a book from the library through their mobile } \\
\text { phones. We have found similar records in [5,22]. }\end{array}$ \\
\hline $\begin{array}{l}\text { Preferred form of } \\
\text { education }\end{array}$ & $\begin{array}{l}\text { In our survey, the students have preferred video lectures and interaction with teachers as their most preferred form of } \\
\text { education where as they chose educational games as their least preferred form of education. They also mentioned that } \\
\text { MCQ is the most feasible evaluation method and True/False questions are the second most feasible evaluation method } \\
\text { whereas Fill in the Gaps is the least feasible evaluation method. Paper [20] mentioned that students have interest in } \\
\text { video lectures and [35] mentioned about video conferencing. Paper [36] mentioned that the average time that a student } \\
\text { can focus on a topic is } 10 \text { to } 15 \text { minutes and suggested to divide a long lecture into several small lectures. Their study } \\
\text { also found that students support taking short assessments like MCQs regularly for better learning. According to [34] } \\
\text { students also preferred doing their assignments collaboratively. }\end{array}$ \\
\hline $\begin{array}{c}\text { Drawbacks and } \\
\text { possible improvements }\end{array}$ & $\begin{array}{l}\text { Students have agreed that the lack of technical knowledge is one of the major drawback of m-learning. They also } \\
\text { identified that the verification of learning success is difficult. Furthermore, they have agreed that higher self-discipline } \\
\text { and is also necessary for m-learning. } \\
\text { According to the students, faster data transmission and larger display devices can make mobile learning achieve a } \\
\text { broader acceptance whereas unifying technologies is not a major concern for the mobile learning acceptance rate. We } \\
\text { have found similar records in [6,10]. }\end{array}$ \\
\hline Degree of success & $\begin{array}{l}\text { In our literature review, we found that m-learning removes the restrictions of traditional learning [3] and enables a } \\
\text { learner to learn beyond traditional learning environments. In our survey, students have also responded positively that } \\
\text { they think a mobile learning software will be helpful for them to improve their learning success. }\end{array}$ \\
\hline
\end{tabular}


Table 4. Discussion based on survey data of teachers

\begin{tabular}{|c|c|}
\hline Category & Summary of teacher's survey data \\
\hline $\begin{array}{l}\text { Usage of mobile } \\
\text { phones in teaching } \\
\text { procedure }\end{array}$ & $\begin{array}{l}\text { Exactly half of the teachers responding the survey, have used mobile device to improve their teaching skills and } \\
\text { methods. More than half of the teachers never used a mobile device as a teaching or learning tool with the students. } \\
\text { Furthermore, most of the teachers never shared any learning materials with the students through their phones. In [8], } \\
\text { authors have expressed their concern mentioning the same. }\end{array}$ \\
\hline $\begin{array}{l}\text { Willingness of mobile } \\
\text { phones for teaching }\end{array}$ & $\begin{array}{l}\text { In our literature review, we found that m-learning can be challenging as a result of unwillingness of the teachers [8]. In } \\
\text { our survey, a major portion }(65 \%) \text { of the teachers expressed that they would like their students to be able to use their } \\
\text { mobile phones for learning purpose inside classroom. We have learned from [3] that is easier to cheat in exams and } \\
\text { agreeing with the same, almost all the teachers answered that they will not like to take exams through mobile phones. } \\
\text { The teachers were divided in exactly halves in terms of providing instructions or notices through mobile phones and } \\
\text { about participating in a live chat rooms with students for discussing subject matters. }\end{array}$ \\
\hline $\begin{array}{l}\text { Activities performed } \\
\text { in mobile phones }\end{array}$ & $\begin{array}{l}\text { Our survey found that teachers usually use mobile devices for communication, capturing photos, reading or editing } \\
\text { documents and watching videos. Less than half of the teachers also use mobile phone for monetary transactions. A } \\
\text { concern about proper security existed for rest of the teachers who do not use mobile phone for transaction purpose. } \\
\text { Authors of [34] also found security concern like data and privacy loss among teachers. }\end{array}$ \\
\hline $\begin{array}{c}\text { Drawbacks and } \\
\text { possible improvements }\end{array}$ & $\begin{array}{l}30 \% \text { of the teachers have ranked Lack of Devices as } 1^{\text {st }} \text { and another } 25 \% \text { of the teachers have ranked Lack of Internet } \\
\text { as } 2^{\text {nd }} \text { biggest obstacle of using mobile devices for teaching purpose. On the other hand, } 25 \% \text { of teachers expressed that } \\
\text { Lack of Training is the smallest obstacle to apply m-learning indicating they are already properly skilled and trained. } \\
\text { According to [37], teachers also face issues with internet connectivity during online classes and teachers also felt that } \\
\text { they required more training for conducting classes online. Authors of [6] have expressed the same concern about } \\
\text { internet accessibility and network infrastructures whereas authors of [10] expressed the same concern about display } \\
\text { size. } \\
\text { In response to another question a } 40 \% \text { of the teachers could not decide whether m-learning would be more stressful } \\
\text { than face to face teaching or not but another } 40 \% \text { of teachers expressed that m-learning will not be more stressful. } \\
\text { Teachers also think that m-learning will not make them to depend on internet over thinking creatively for practical } \\
\text { work. } \\
\text { Teachers also responded that faster data transmission, lower network traffic and larger display are necessary for m- } \\
\text { learning to achieve a broader common acceptance. They also expressed that larger memory capacity is not a major } \\
\text { necessity for the purpose. Paper [38] expressed concern about performance based on memory capacity and bandwidth } \\
\text { limitation. }\end{array}$ \\
\hline $\begin{array}{l}\text { Teacher's vision on } \\
\text { M-learning }\end{array}$ & $\begin{array}{l}\text { Our survey responses highlighted that half of the teachers expressed that the acceptance of m-learning among the } \\
\text { students in higher education will be high. A major portion of the teachers agreed that m-learning can bring massive } \\
\text { opportunities for the universities to empower informal learning. Authors of [17] also stated that m-learning has added a } \\
\text { new dimension to learning by enabling a learner to go beyond traditional learning experiences. } \\
\text { Teachers expressed that m-learning will play an important role in the future of learning. They also positively think to } \\
\text { adopt and integrate m-learning technology for their teaching methodology. Authors of [3] mentioned that m-learning is } \\
\text { cost efficient and increases the opportunity of learning. }\end{array}$ \\
\hline
\end{tabular}

In any learning environment, students and teachers are the major stakeholders. Our survey questionnaires focused on the facilities of an m-learning environment from the perspective of these two major stakeholders. As a result, the findings discussed in this paper will help researchers to learn about the facilities that are required for both students and teachers for acting in a mobile learning environment.

\section{Conclusion}

Our paper observed utilization of mobile phones by students and teacher of higher education in regular learning and how m-learning is being approached by them. Survey data was compared with existing literature and it was found that students are expected to be self-directed learners who independently locate resources to supplement their learning. Using mobile devices for learning outside the classroom can also be a motivating factor for them. Furthermore, we found that students are not only interested in receiving course contents but also in interacting among themselves and with the course teacher through mobile phone. It was also found that teachers are ready to adapt mobile learning and they believe that mobile learning will play a significant role in the future of learning.

Although our paper studied positive roles with respect to mobiles as a tool from the perspective of students and teachers to either access learning resources or provide more learner-centered curriculum. Future researches can investigate whether using mobile device has an impact on academic performance of the students.

\section{References}

[1] M. Habib, "An empirical research of ITESCM (integrated tertiary educational supply chain management) model," Management and Services, 2010.

[2] M. Habib, "An Integrated Educational Supply Chain Management (ITESCM)," Ph.D. Dissertation, Graduate School of Information Technology, 2009.

[3] M. Sarrab, "Mobile Learning (M-Learning) and Educational Environments," International Journal of Distributed and Parallel systems, vol. 3, no. 4, pp. 31-38, 2012.

[4] J. Hossain, M. A. Hoque, and M. J. Uddin, "Private University: In Expanding Higher Educational Facilities in Bangladesh," Banglavision Journal, no. 01, pp. 14-14, 2014. 
[5] M. Sarrab, "Exploring Major Challenges and Benefits of M-learning Adoption," British Journal of Applied Science \& Technology, vol. 3, no. 4, pp. 826-839, 2013.

[6] K. Aghigh and M. Bodaghi, "Learning Methods and Concepts Used in Mobile Learning and how to Improve Them Using new Approaches," in 6th International Conference on e-Learning, University of British Columbia Okanagan, Kelowna British Columbia Canada (P. Balcaen, ed.), (UK), Academic Publishing Limited, June 2011.

[7] D. Nandi, M. Hamilton, and J. Harland, "What factors impact student - Content interaction in fully online courses," International Journal of Modern Education and Computer Science, vol. 7, pp. 28- 35, 2015.

[8] G. U. Chiaha, J. U. Eze, and F. O. Ezeudu, "Education students' access to e-learning facilities in universities South-East of Nigeria," in Information and Knowledge Management, vol. 3, pp. 32-41, 2013.

[9] S. Kwon and J. E. Lee, "Design principles of m-learning for ESL," Procedia-Social and Behavioral Sciences, vol. 2, no. 2, pp. $1884-1889,2010$.

[10] Y. Tonta, U. Al, P. E. an, and A. Babtista, "Digital publishing and mobile technologies," pp. 150-157, 2011.

[11] Y. Laouris and N. Eteokleous, "We need an educationally relevant definition of mobile learning," Proceedings of mLearn, 2005.

[12] M. L. Koole, "A model for framing mobile learning," Mo- bile learning: Transforming the delivery of education and training, vol. 1, no. 2, pp. 25-47, 2009.

[13] D. Parsons and H. Ryu, "A framework for assessing the quality of mobile learning," Proceedings of the International Conference for Process Improvement, pp. 17-27, 2006.

[14] D. Parsons, H. Ryu, and M. Cranshaw, "A Design Requirements Framework for Mobile Learning Environments,” Journal of Computers, vol. 2, no. 4, pp. 1-8, 2007.

[15] I. I. I. Clarke and T. B. Flaherty, "Mobile portals: The development of m-commerce gateways," Mobile commerce: Technology, theory and applications, pp. 185-201, 2003.

[16] R. Oller, "The future of mobile learning," ECAR Research Bulletin, (Boulder CO: EDUCAUSE Center for Applied Research, 2012.

[17] N. Winters, "What is mobile learning," Big issues in mobile learning, pp. 7-11, 2007.

[18] R. Kaliisa, E. Palmer, and J. Miller, "Mobile learning in higher education: A comparative analysis of developed and developing country contexts," British Journal of Educational Technology, vol. 50, no. 2, pp. 546-561, 2019.

[19] D. Nandi, M. Hamilton, J. Harland, and S. Mahmood, "Investigation of participation and quality of online interaction," International Journal of Modern Education and Computer Science, vol. 7, no. 8, p. 25, 2015.

[20] A. J. Litchfield, L. E. Dyson, E. M. Lawrence, and A. Bachfischer, "Directions for m-learning research to enhance active learning," Annual Conference of the Australasian Society for Computers in Learning in Tertiary Education, 2007.

[21] D. M. West, "Mobile learning: Transforming education, engaging students, and improving outcomes," Brookings Pol- icy Report, pp. 1-7, 2013.

[22] T. D. Senta and T. Tschang, Access to knowledge: New information technologies and the emergence of the virtual university. Elsevier Science Inc., 2000.

[23] V. Krotov, "Critical Success Factors in M-Learning: A Socio-Technical Perspective," Communications of the Association for Information Systems, vol. 36, no. 1, pp. 6-6, 2015.

[24] A. Oulasvirta, M. Wahlström, and K. A. Ericsson, "What does it mean to be good at using a mobile device? An investigation of three levels of experience and skill,” International Journal of Human-Computer Studies, vol. 69, no. 3, pp. 155-169, 2011.

[25] F. Balagtas-Fernandez, J. Forrai, and H. Hussmann, "Evaluation of user interface design and input methods for applications on mobile touch screen devices," in IFIP Conference on Human-Computer Interaction, pp. 243-246, 2009.

[26] R. Naish, "Youth engaged by m-learning," E-learning Age, vol. 2, pp. 16-17, 2005.

[27] D. Guralnich, "The importance of the learner's environmental context in the design of M-learning products," International Journal of Interactive Mobile Technologies, vol. 2, no. 1, pp. 36-39, 2008.

[28] K. Gyeung-Min and S. M. Ong, "An exploratory study of factors influencing m-learning success," The Journal of Computer Information Systems, vol. 46, no. 1, pp. 92-92, 2005.

[29] A. Mostakhdemin-Hosseini, "Analysis of Pedagogical Considerations of M-Learning in Smart Devices," International Journal of Interactive Mobile Technologies (iJIM), vol. 3, no. 4, 2009.

[30] R. Sagor, Guiding school improvement with action research. Ascd, 2000

[31] N. O. Keskin and A. Kuzu, "Development and testing of a m-learning system for the professional development of academics through design-based action research," International Review of Research in Open and Distributed Learning, vol. 16, no. 1, pp. 193-220, 2015.

[32] D.-B. R. Collective, "Design-based research: An emerging paradigm for educational inquiry," Educational Researcher, vol. 32, no. 1 , pp. 5-8, 2003

[33] A. Pinsonneault and K. Kraemer, "Survey Research Methodology in Management Information Systems: An Assessment," Journal of Management Information Systems, vol. 10, no. 2, pp. 75-105, 1993.

[34] O. W. Adejo, I. Ewuzie, A. Usoro, and T. Connolly, "E- learning to m-learning: framework for data protection and security in cloud infrastructure," International Journal of Information Technology and Computer Science (IJITCS), vol. 10, no. 4, pp. 19, 2018. DOI: 10.5815/ijitcs.2018.04.01

[35] E.G. Dada, A. H. Alkali, and D. O. Oyewola, "An Investigation into the Effectiveness of Asynchronous and Synchronous Elearning Mode on Students' Academic Performance in National Open University (NOUN), Maiduguri Centre.," International Journal of Modern Education and Computer Science, vol. 11, no. 5, 2019.

[36] A. Khan and J. Madden, "Active learning: a new assessment model that boost confidence and learning while reducing test anxiety," International Journal of Modern Education and Computer Science, vol. 10, no. 12, p. 1, 2018.

[37] M. M. Hassan, T. Mirza, and M. W. Hussain, "A Critical Review by Teachers on the Online Teaching-Learning during the COVID-19", International Journal of Education and Management Engineering (IJEME), Vol.10, No.5, pp.17-27, 2020. DOI: 10.5815/ijeme.2020.05.03. 
[38] A. O. Baalghusun and M. R. J. Qureshi, “A novel model for cloud based mobile learning system," International Journal of Information Engineering and Electronic Business, vol. 6, no. 6, p. 40, 2014.

\section{Appendix A}

Student survey questionnaire:

Q1. Do you use or want to use mobile devices in learning regularly?

Q2. Do you have internet access through a cellular network on your mobile phone?

Q3. Do you have internet access through a Wi-Fi connection on your mobile phone?

Q4. Do you feel comfortable to read books in your phone?

Q5. Would you feel comfortable to give online test through mobile phone?

Q6. Would you agree that having course materials such as slides, lecture notes, and practice quizzes available on your mobile phone would be beneficial to your study process?

Q7. Would you feel comfortable receiving grades through mobile phone?

Q8. Would you be comfortable if your professor contacts and guides you through mobile devices?

Q9. Which of the following personal activities do you currently engage in on your handheld mobile device?

Q10. What mobile tools do you use in class?

Q11. Which learning resources would you be interested in accessing on a mobile phone?

Q12. Which information technology services would you be interested in accessing on a mobile device.

Q13. Which library services would you be interested in accessing on a handheld mobile device?

Q14. Which form of education is preferable to you? (Assign Priority from 1 to 6: 1= most Preferable, 6= Least Preferable)

Q15. Which form of evaluation do you find feasible for the mobile phone?

Q16.Which of the disadvantages of mobile learning do you agree with?

Q17. What do mobile learning need to achieve broader acceptance?

Q18. Do you feel that the use of some kind of mobile learning software would improve your overall success in your learning?

Teacher survey questionnaire:

Q1. Have you ever used a mobile device to develop your own teaching methods?

Q2. Have you ever used a mobile device as a teaching or learning tool with students?

Q3. Have you ever shared learning materials with your students through mobile phones?

Q4. Would you like your students to have and to be able to use mobile devices in your class for learning purpose?

Q5. Would you like to take exams through mobile phone?

Q6. Do you feel comfortable to provide instructions, notices through mobile phone to your students?

Q7. Do you like to participate in a live chat room with your students to broadcast instructions or discuss subject matters?

Q8. Which of the following personal activities do you currently engage in on your handheld mobile device?

Q9. What do you see as the biggest obstacle to use mobile learning in your teaching? (Assign Rank from 1 to 6: 1= Biggest Obstacle, $6=$ Smallest Obstacle)

Q10. Do you agree that Mobile-Learning is too stressful compared to face-to-face teaching?

Q11. Do you agree that Mobile Learning can make teachers to depend on internet without thinking creatively for practical work in the classroom?

Q12.What would be needed for mobile learning so that it can achieve broader common acceptance? (Assign Priority from 1 to 5: Most Needed $=1$, Least Needed $=5$ )

Q13. Student acceptance of Mobile Learning in higher education would be high.

Q14. Mobile Learning can bring enormous opportunities into universities to further empower informal learning.

Q15. Do you think mobile learning would play an important role in the future of learning?

Q16. Do you think with just the right amount of training, teachers may wish to adopt and integrate M-Learning technology for their teaching methodology?

\section{Authors' Profiles}

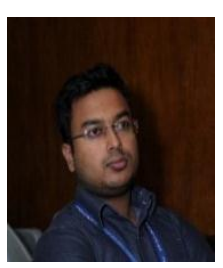

Mohaimen-Bin-Noor is currently working as a Lecturer in American International University- Bangladesh and has completed his B.Sc. in Computer Science \& Engineering and M.Sc. in Computer Science from AIUB. His current research interest includes M-learning, Graph Algorithms and IoT. He can be contacted at mohaimen.niloy@aiub.edu. 


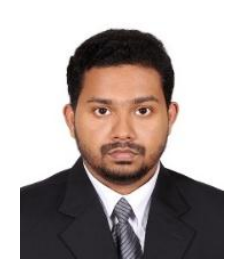

Zahiduddin Ahmed is currently pursuing his Ph.D. at University Malaysia Pahang in Machine Learning and working as a Graduate Research Assistant. His research interest includes Artificial Intelligence, Data and Text Mining, Machine Learning, Natural Language Processing and Knowledge Management. He can be contacted at ahmedchayon11@gmail.com.

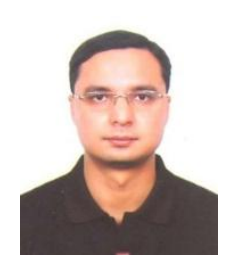

Dr. Dip Nandi is currently working as an Associate Professor and Director of Faculty of Science and Technology in American International University- Bangladesh. His research interest includes Software Engineering, Management Information Systems, E-learning etc. He can be contacted at dip.nandi@aiub.edu.

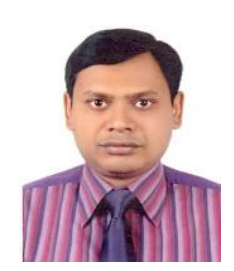

Mashiour Rahman is working as an Associate Professor and Associate Dean of Faculty of Science and Technology in American International University- Bangladesh. His research interest includes Algorithms, Data structure, M-learning etc. He can be contacted at mashiour@aiub.edu.

How to cite this paper: Mohaimen-Bin-Noor, Zahiduddin Ahmed, Dip Nandi, Mashiour Rahman, " Investigation of Facilities for an M-learning Environment ", International Journal of Modern Education and Computer Science(IJMECS), Vol.13, No.1, pp. 34-48, 2021.DOI: 10.5815/ijmecs.2021.01.03 